\title{
Salt Tolerance of Muskmelons Grown in Different Media
}

\author{
Akira Nukaya, Masao Masui and Akira Ishida \\ College of Agriculture, Shizuoka University, Ohya, Shizuoka 422
}

\begin{abstract}
Summary
Muskmelons were grown under the same environmental conditions to determine levels of salt tolerance in different media. Plant height at harvest decreased with increasing sea water concentrations in sand and soil cultures. The relative plant dry weight and fruit fresh weight were greatest in nutrient solution culture, followed by soil culture and least in sand culture. The relative fruit fresh weights at $1,000 \mathrm{ppm} \mathrm{Cl}$ as compared to $0 \mathrm{ppm} \mathrm{Cl}$ in sand, soil and nutrient solution cultures were $66.2,70.5$ and $91.1 \%$, respectively. Osmotic potential of leaves and roots decreased, and $\mathrm{Cl}$ content in each plant part, and $\mathrm{Na}$ and $\mathrm{Mg}$ in leaves increased with increasing sea water concentrations in each medium. The relative $\mathrm{Cl}$ and $\mathrm{Na}$ content in leaves was highest in sand culture and lowest in nutrient solution culture. $\mathrm{Cl}$ and exchangeable $\mathrm{Na}$ in soil and sand, and $\mathrm{EC}$ of soil increased with increasing sea water concentrations. Anion and cation content, and EC of media were greater in soil culture than in sand culture.
\end{abstract}

\section{Introduction}

Because the salinity of well water originated from sea water (11), salt tolerance of muskmelens (Cucumis melo L. cv. Earl's Favourite) was determined in sand, soil and nutrient solution cultures by applying diluted sea water $(14,15)$. These experiments showed that the marginal diluted sea water concentration which decreased the fruit weight was $250 \mathrm{ppm} \mathrm{Cl}$ in sand and soil cultures, and $2,000 \mathrm{ppm} \mathrm{Cl}$ in nutrient solution culture. Also, the salt injury symptoms began to appear at $250 \mathrm{ppm} \mathrm{Cl}$ in sand culture and $1,000 \mathrm{ppm} \mathrm{Cl}$ in soil and nutrient solution cultures. Thus, muskmelons seemed to be most tolerant to diluted sea water in nutrient solution culture, less tolerant in soil culture, and least tolerant in sand culture. Differences in salt tolerance may be induced by environmental factors, such as light intensity, day length, temperature of room and medium, humidity, total soil moisture stress, and salt accumulation in media $(1,8,9,19)$ and the plant characteristics, such as top-root ratios, root system,

Received for publication June 10, 1980. and the stage of growth at which salinization occurred $(3,4,10)$. The previous experiments were carried out at different times using diluted sea water with tap water in soil culture and with base nutrient solution in sand and nutrient solution cultures. Therefore, in this experiment muskmelons were grown under the same environmental conditions at the same time to determine differences in salt tolerance and major elements in plants grown in different media.

\section{Materials and Methods}

Treatments were applied in a factorial arrangement involving 4 levels of diluted sea water, and 3 kinds of culture media. Thus there were 12 treatments, each having 5 replications, with a total of 60 single plant plots. Sea water taken at Miho seaside was diluted with base nutrient solution to make 4 treatment levels $(0,250,500$ and $1,000 \mathrm{ppm} \mathrm{Cl}$ ) as shown in Table 1 . The media were Takamatsu light clay paddy soil, taken at Shizuoka, Tenryu River sand and nutrient solution in soil, sand and nutrient solution cultures. Fourteen liters of the soil mixed with 7 liters of decomposed rice straw, or 14 liters of the sand were put into a 
Table 1. Cation concentrations and EC in relation to sea water diluted with base nutrient solution. $* *$

\begin{tabular}{r|c|c|c|c|c|c|c}
\hline \hline \multicolumn{2}{c|}{ Sea water concentrations* } & \multicolumn{4}{|c|}{ Cations (ppm) } & EC \\
\cline { 2 - 5 } $\begin{array}{c}\mathrm{Cl} \\
(\mathrm{ppm})\end{array}$ & $\begin{array}{c}\text { Osmotic potential } \\
\text { (bars) }\end{array}$ & $\%$ & $\mathrm{~K}$ & $\mathrm{Na}$ & $\mathrm{Ca}$ & $\mathrm{Mg}$ & $(\mathrm{m} / \mathrm{cm})$ \\
\hline 0 & -0.69 & 0 & 235 & 44 & 232 & 46 & 2.43 \\
250 & -1.02 & 1.25 & 241 & 170 & 237 & 61 & 3.03 \\
500 & -1.35 & 2.50 & 246 & 296 & 242 & 78 & 3.87 \\
1,000 & -2.02 & 5.00 & 257 & 548 & 252 & 109 & 4.96 \\
\hline
\end{tabular}

*: Sea water contains $20,500 \mathrm{ppm} \mathrm{Cl}, 445 \mathrm{ppm} \mathrm{K}, 10,082 \mathrm{ppm} \mathrm{Na}, 393 \mathrm{ppm} \mathrm{Ca}$ and $1,262 \mathrm{ppm} \mathrm{Mg}$.

** : Composition of base nutrient solution; $\mathrm{Na}_{2} \mathrm{HPO}_{4} \cdot 12 \mathrm{H}_{2} \mathrm{O}=0.5 \mathrm{mM}, \mathrm{K}_{2} \mathrm{SO}_{4}=$ $3 \mathrm{mM}, \mathrm{Ca}\left(\mathrm{NO}_{3}\right)_{2} \cdot 4 \mathrm{H}_{2} \mathrm{O}=4 \mathrm{mM}, \mathrm{MgSO}_{4} \cdot 7 \mathrm{H}_{2} \mathrm{O}=2 \mathrm{mM}$, and minor elements ( $\mathrm{Mn}, \mathrm{Fe}, \mathrm{Zn}, \mathrm{Cu}, \mathrm{B}$ and $\mathrm{Mo}$ ). $\mathrm{pH}=6.0$

wooden box $(40 \times 40 \times 20 \mathrm{~cm})$. Four-leafed seedlings, cv. Spring No. 3 of Earl's Favourite grafted on Barnett Hill Favourite rootstocks, were transplanted into boxes in sand and soil cultures on April 19, 1976. The treatment solution was applied to the media 1 or 3 times a day whether it was cloudy or sunny, from April 16 to harvesting (early July). No solution was applied on rainy days. In nutrient solution culture, each treatment solution was put into 13 liter pots, and identical seedlings with sand and soil cultures were transferred to the pots on April 19, 1976. The solution was replaced every 2 weeks for the first 6 weeks and every week after that and aerated continuously. To maintain a constant solution volume tap water was added to pots to compensate for transpiration losses. The experiment was carried out under uniform

Table 2. Effect of sea water concentrations on grow th of muskmelons grown in different media.

\begin{tabular}{|c|c|c|c|c|c|c|c|c|}
\hline \multicolumn{3}{|c|}{ Treatments } & \multicolumn{2}{|c|}{ Plant ht. $(\mathrm{cm})^{*}$} & \multicolumn{3}{|c|}{ Fresh wt. (g) } & \multirow{2}{*}{$\begin{array}{c}\text { Dry wt. of whole } \\
\text { plant (g) }\end{array}$} \\
\hline $\mathrm{Nc}$ & Media & $\begin{array}{c}\text { Sea water concns } \\
(\text { ppm Cl })\end{array}$ & May 15 & At harvest & Leaves & Stem & Roots & \\
\hline 1 & \multirow{4}{*}{ Soil } & 0 & $110^{\mathrm{b}}$ & $117^{\mathrm{abc}}$ & $324^{\mathrm{c}}$ & $240^{\mathrm{d}}$ & $22^{\mathrm{c}}$ & $188^{d}(100.0)^{* *}$ \\
\hline 2 & & 250 & $110^{b}$ & $118^{\mathrm{ab}}$ & $305^{c}$ & $250^{\mathrm{d}}$ & $22^{\mathrm{c}}$ & $182^{\mathrm{d}}(96.8)$ \\
\hline 3 & & 500 & $108^{\mathrm{bc}}$ & $114^{\mathrm{bcd}}$ & $345^{\mathrm{c}}$ & $258^{\mathrm{d}}$ & $23^{\mathrm{c}}$ & $183^{d}(97.3)$ \\
\hline 4 & & 1,000 & $100^{d}$ & $109^{d}$ & $327^{\mathrm{c}}$ & $242^{\mathrm{d}}$ & $22^{c}$ & $157^{\mathrm{e}}(83.5)$ \\
\hline 5 & \multirow{4}{*}{ Sand } & 0 & $118^{\mathrm{a}}$ & $121^{\mathrm{a}}$ & $523^{\mathrm{ab}}$ & $311^{\mathrm{ab}}$ & $50^{c}$ & $284^{a}(100.0)$ \\
\hline 6 & & 250 & $107^{b c}$ & $108^{d}$ & $492^{\mathrm{b}}$ & $305^{b}$ & $36^{\mathrm{c}}$ & $241^{c}(84.9)$ \\
\hline 7 & & 500 & $103^{\mathrm{d}}$ & $108^{\mathrm{d}}$ & $496^{\mathrm{b}}$ & $305^{\mathrm{b}}$ & $34^{\mathrm{c}}$ & $230^{c}(81.0)$ \\
\hline 8 & & 1,000 & $84^{\mathrm{e}}$ & $90^{\mathrm{e}}$ & $367^{\mathrm{c}}$ & $250^{d}$ & $22^{\mathrm{c}}$ & $159^{\mathrm{e}}(56.0)$ \\
\hline 9 & \multirow{4}{*}{ Solution } & 0 & $107^{\mathrm{bc}}$ & $110^{\mathrm{cd}}$ & $522^{\mathrm{ab}}$ & $280^{\mathrm{c}}$ & $200^{a}$ & $268^{\mathrm{ab}}(100.0)$ \\
\hline 10 & & 250 & $111^{\mathrm{b}}$ & $119^{a b}$ & $568^{\mathrm{a}}$ & $330^{\mathrm{a}}$ & $207^{a}$ & $270^{\mathrm{ab}}(100.8)$ \\
\hline 11 & & 500 & $109^{b}$ & $113^{\mathrm{bcd}}$ & $537^{a b}$ & $333^{\mathrm{a}}$ & $169^{b}$ & $250^{\mathrm{bc}}(93.3)$ \\
\hline 12 & & 1,000 & $102^{\mathrm{d}}$ & $107^{d}$ & $538^{a b}$ & $331^{\mathrm{a}}$ & $151^{\mathrm{b}}$ & $244^{c}(91.0)$ \\
\hline \multirow{4}{*}{\multicolumn{2}{|c|}{ Mean $\mathrm{Cl}$ concns }} & 0 & $112^{\mathrm{A}}$ & $116^{\mathrm{A}}$ & $457^{\mathrm{A}}$ & $277^{\mathrm{B}}$ & $91^{\mathrm{A}}$ & $247^{\mathrm{A}}$ \\
\hline & & 250 & $110^{\mathrm{A}}$ & $115^{\mathrm{AB}}$ & $455^{\mathrm{A}}$ & $295^{\mathrm{A}}$ & $88^{\mathrm{A}}$ & $231^{\mathrm{B}}$ \\
\hline & & 500 & $108^{\mathrm{B}}$ & $112^{\mathrm{B}}$ & $459^{\mathrm{A}}$ & $299^{\mathrm{A}}$ & $75^{\mathrm{AB}}$ & $221^{\mathrm{B}}$ \\
\hline & & 1,000 & $95^{\mathrm{C}}$ & $102^{\mathrm{C}}$ & $410^{\mathrm{B}}$ & $274^{\mathrm{B}}$ & $65^{\mathrm{B}}$ & $187^{\mathrm{C}}$ \\
\hline \multirow{3}{*}{\multicolumn{2}{|c|}{ Mean media }} & Soil & $107^{x}$ & $115^{x}$ & $325^{Z}$ & $247^{z}$ & $22^{\mathrm{Y}}$ & $178^{z}$ \\
\hline & & Sand & $103^{\mathrm{Y}}$ & $107^{\mathrm{Y}}$ & $469^{\mathrm{Y}}$ & $293^{\mathrm{Y}}$ & $35^{\mathrm{Y}}$ & $228^{\mathrm{Y}}$ \\
\hline & & & $107^{x}$ & $112^{\mathrm{x}}$ & $541^{x}$ & $319^{x}$ & $182^{x}$ & $258^{\mathrm{x}}$ \\
\hline
\end{tabular}

* : Mean separation followed by the same letter within columns by Duncan's multiple range test, $5 \%$ level.

**: Figures in parentheses show percentage of $0 \mathrm{ppm} \mathrm{Cl}$ in each medium. 
Table 3. Effect of sea water concentrations on fruit weight and quality of muskmelons grown in different media (\% of dry matter).

\begin{tabular}{|c|c|c|c|c|c|c|}
\hline \multicolumn{3}{|c|}{ Treatments } & \multirow[b]{2}{*}{ Fresh wt. ${ }^{*}(\mathrm{~g})$} & \multirow{2}{*}{$\begin{array}{c}\text { Soluble solids } \\
\qquad(\%)\end{array}$} & \multirow{2}{*}{$\begin{array}{l}\text { External*** } \\
\text { appearance }\end{array}$} & \multirow[b]{2}{*}{ Salty taste $e^{* * * *}$} \\
\hline No. & Media & $\begin{array}{l}\text { Sea water concns } \\
(p p m C l)\end{array}$ & & & & \\
\hline $\begin{array}{l}1 \\
2 \\
3 \\
4\end{array}$ & Soil & $\begin{array}{r}0 \\
250 \\
500 \\
1,000\end{array}$ & $\begin{array}{cl}1,348^{\mathrm{cde}} & (100.0)^{* *} \\
1,284^{\mathrm{e}} & (95.3) \\
1,242^{\mathrm{ef}} & (92.1) \\
950^{\mathrm{g}} & (70.5)\end{array}$ & $\begin{array}{l}14.7^{\mathrm{bcd}} \\
14.9^{\mathrm{abc}} \\
15.7^{\mathrm{ab}} \\
15.9^{\mathrm{a}}\end{array}$ & $\begin{array}{l}7.1^{\mathrm{cde}} \\
7.2^{\mathrm{cde}} \\
7.2^{\mathrm{cde}} \\
5.6^{\mathrm{f}}\end{array}$ & $\begin{aligned} & 0 \\
& 0 \\
& 0 \sim 0.5 \\
& 1 \sim 2\end{aligned}$ \\
\hline $\begin{array}{l}5 \\
6 \\
7 \\
8\end{array}$ & Sand & $\begin{array}{r}0 \\
250 \\
500 \\
000\end{array}$ & $\begin{array}{ll}1,673^{\mathrm{a}} & (100.0) \\
1,494^{\mathrm{bc}} & (89.5) \\
1,332^{\text {de }} & (79.6) \\
1,108^{\mathrm{f}} & (66.2)\end{array}$ & $\begin{array}{l}14.6^{\mathrm{cd}} \\
14.5^{\mathrm{cd}} \\
14.3^{\mathrm{cd}} \\
12.8^{\mathrm{e}}\end{array}$ & $\begin{array}{l}9.3^{\mathrm{a}} \\
9.5^{\mathrm{a}} \\
9.0^{\mathrm{ab}} \\
6.5^{\mathrm{e}}\end{array}$ & $\begin{array}{c}0 \\
0 \\
0 \sim 0.5 \\
0 \sim 0.5\end{array}$ \\
\hline $\begin{array}{r}9 \\
10 \\
11 \\
12\end{array}$ & Solution & $\begin{array}{r}0 \\
250 \\
500 \\
1,000 \\
\end{array}$ & $\begin{array}{ll}1,593^{\mathrm{ab}} & (100.0) \\
1,551^{\mathrm{ab}} & (97.4) \\
1,500^{\mathrm{bc}} & (94.2) \\
1,451^{\mathrm{bcd}} & (91.1)\end{array}$ & $\begin{array}{l}13.5^{\mathrm{de}} \\
13.9^{\mathrm{cde}} \\
13.6^{\mathrm{de}} \\
13.8^{\mathrm{cde}}\end{array}$ & $\begin{array}{l}8.3^{\mathrm{abc}} \\
7.6^{\mathrm{cde}} \\
7.0^{\mathrm{de}} \\
7.9^{\mathrm{bcd}}\end{array}$ & $\begin{array}{c}0 \\
0 \\
0 \\
0.5\end{array}$ \\
\hline \multicolumn{2}{|c|}{ Mean $\mathrm{Cl}$ concns } & $\begin{array}{r}0 \\
250 \\
500 \\
1,000\end{array}$ & $\begin{array}{l}1,538^{\mathrm{A}} \\
1,443^{\mathrm{B}} \\
1,358^{\mathrm{C}} \\
1,170^{\mathrm{D}}\end{array}$ & $\begin{array}{l}14.3^{\mathrm{A}} \\
14.5^{\mathrm{A}} \\
14.5^{\mathrm{A}} \\
14.2^{\mathrm{A}}\end{array}$ & $\begin{array}{l}8.2^{\mathrm{A}} \\
8.1^{\mathrm{A}} \\
7.7^{\mathrm{A}} \\
6.7^{\mathrm{B}}\end{array}$ & \\
\hline \multicolumn{2}{|c|}{ Mean media } & $\begin{array}{c}\text { Soil } \\
\text { Sand } \\
\text { Solution }\end{array}$ & $\begin{array}{l}1,206^{\mathrm{Z}} \\
1,402^{\mathrm{Y}} \\
1,524^{\mathrm{X}}\end{array}$ & $\begin{array}{l}15.3^{X} \\
14.1^{Y} \\
13.7^{Y}\end{array}$ & $\begin{array}{l}6.8^{Z} \\
8.6^{\mathrm{X}} \\
7.7^{Y}\end{array}$ & \\
\hline
\end{tabular}

$*, * *:$ The same as Table 2 .

$* * *:$ Full score $=10$.

$* * * *: 0=$ none, $0.5=$ minimal salty, $1=$ slightly salty and $2=$ salty.

conditions in the greenhouse until harvesting. At the end of the experiment measurements were made of plant growth, osmotic potential of leaves and roots, and chemical properties of sand and soil. The treatment solution was sampled and analyzed when changed. The analytical methods were the same as described previously (12).

\section{Results}

Growth and fruit quality (Table 2 and 3) The early growth as expressed by plant height on May 15 was restricted at 1,000 $\mathrm{ppm} \mathrm{Cl}$ in each medium, especially in sand culture. Plant height at harvest decreased with increasing sea water concentrations in sand and soil cultures. Fresh weight of leaves, stem and roots was markedly decreased at $1,000 \mathrm{ppm} \mathrm{Cl}$ as compared to $0 \mathrm{ppm}$ $\mathrm{Cl}$ in sand culture, and tended to be greater at $250 \mathrm{ppm} \mathrm{Cl}$ in nutrient solution culture. There was no significant difference in fresh weight of plant parts in soil culture.
Whole plant dry weight was relatively small at $1,000 \mathrm{ppm} \mathrm{Cl}$ in soil culture, and decreased with increasing sea water concentrations in sand and nutrient solution cultures. The whole plant dry weight as expressed by percentage of $0 \mathrm{ppm} \mathrm{Cl}$ was greatest in nutrient solution culture, followed by soil culture and then sand culture. The salt injury symptom, a wilting of leaf margin, was slight at $1,000 \mathrm{ppm} \mathrm{Cl}$ in sand and soil cultures. Fruit fresh weight decreased with increasing sea water concentrations in each medium. The decrement was greatest in sand culture. Fruit fresh weight at 1,000 $\mathrm{ppm} \mathrm{Cl}$ as compared to $0 \mathrm{ppm} \mathrm{Cl}$, in sand, soil and nutrient solution cultures, was 66.2 , 70.5 and $91.1 \%$, respectively. There was no distinct difference in soluble solids of fruit in the same medium. Scores of external appearance were higher in sand culture than in the others. They decreased at 1,000 $\mathrm{ppm} \mathrm{Cl}$ in sand and soil cultures. Fruit taste was slightly salty at $500 \mathrm{ppm} \mathrm{Cl}$ in sand and 
soil cultures, and at $1,000 \mathrm{ppm} \mathrm{Cl}$ in nutrient solution culture. In soil culture the taste at $1,000 \mathrm{ppm} \mathrm{Cl}$ was saltier than at $500 \mathrm{ppm}$ $\mathrm{Cl}$.

Osmotic potential of leaves and roots and Cl content in plant parts (Table 4) Osmotic potential of leaves and roots decreased with increasing sea water concentrations in sand and soil cultures, and was not significantly different in nutrient solution culture. The osmotic potential in nutrient solution culture was higher than in sand and soil cultures. $\mathrm{Cl}$ content in each plant part tended to increase with increasing sea water concentrations in each medium. $\mathrm{Cl}$ content in leaves at $1,000 \mathrm{ppm} \mathrm{Cl}$ as compared to $0 \mathrm{ppm} \mathrm{Cl}$ in sand, soil and nutrient solution cultures was $6.7,4.8$ and 3.1 times, respectively. Salty taste of fruit seemed to be correlated to the $\mathrm{Cl}$ content in fruit.

Major elements in leaves (Table 5) $\mathrm{Na}$ and $\mathrm{Mg}$ content in leaves increased with increasing sea water concentrations in each medium. The increment of $\mathrm{Na}$ was greater in sand culture than in other cultures. At
$1,000 \mathrm{ppm} \mathrm{Cl}$ as compared to $0 \mathrm{ppm} \mathrm{Cl}$ in sand, soil and nutrient solution cultures, there was $2.9,1.6$ and 1.5 times as much $\mathrm{Na}$, respectively. $\mathrm{K}$ content in soil and sand cultures, and $\mathrm{Ca}$ content in soil and nutrient solution cultures decreased as sea water concentrations increased. There were no significant differences in total- $\mathrm{N}$ and $\mathrm{P}$ content among the same medium.

Chemical properties of soil and sand at the end of the experiment (Table 6) $\mathrm{Cl}$ and exchangeable $\mathrm{Na}$ content in soil and sand cultures, exchangeable $\mathrm{Mg}, \mathrm{NO}_{3}-\mathrm{N}$, and $\mathrm{EC}$ value in soil culture increased with increasing sea water concentrations. However, $\mathrm{EC}$ value, $\mathrm{NO}_{3}-\mathrm{N}$ and exchangeable $\mathrm{Mg}$ were not significantly different in sand culture. Cations and anions, and EC value were greater in soil culture than in sand culture.

\section{Discussion}

The actual values of leaf, stem, root and fruit fresh weight, and whole plant dry weight were greatest in nutrient solution culture, followed by sand culture and then

Table 4. Effect of sea water concentrations on osmotic potential of leaves and roots, and $\mathrm{Cl}$ content in leaves, roots and fruit of muskmelons grown in different media.

\begin{tabular}{|c|c|c|c|c|c|c|c|}
\hline \multicolumn{3}{|c|}{ Treatments } & \multicolumn{2}{|c|}{ Osmotic potential* (bars) } & \multicolumn{3}{|c|}{$\mathrm{Cl}(\%$ of dry matter $)$} \\
\hline No. & Media & $\left|\begin{array}{l}\text { Sea water } \\
\text { concns }(\mathrm{ppm} \mathrm{Cl})\end{array}\right|$ & Leaves & Roots & Leaves & Roots & Fruit \\
\hline 1 & \multirow{4}{*}{ Soil } & 0 & $-9.7^{\mathrm{de}}$ & $-6.3^{c}$ & $0.48^{\mathrm{fg}}$ & 1. $85^{\mathrm{d}}$ & $0.23^{\mathrm{cd}}$ \\
\hline 2 & & 250 & $-11.5^{c}$ & $-7.1^{\mathrm{b}}$ & $1.20^{\mathrm{c}}$ & $3.07^{\mathrm{b}}$ & $0.26^{\mathrm{cd}}$ \\
\hline 3 & & 500 & $-11.9^{a b c}$ & $-7.8^{\mathrm{ab}}$ & 1. $69^{\mathrm{b}}$ & $3.90^{\mathrm{a}}$ & $0.32^{\mathrm{bcd}}$ \\
\hline 4 & & 1,000 & $-12.8^{\mathrm{a}}$ & $-8.2^{\mathrm{a}}$ & 2. $28^{\mathrm{a}}$ & $3.96^{\mathrm{a}}$ & $0.62^{\mathrm{a}}$ \\
\hline 5 & \multirow{4}{*}{ Sand } & 0 & $-10.1^{d}$ & $-5.4^{\mathrm{d}}$ & $0.35^{\mathrm{f} \mathrm{g}}$ & $0.77^{\mathrm{f}}$ & $0.25^{\mathrm{cd}}$ \\
\hline 6 & & 250 & $-11.3^{\mathrm{c}}$ & $-7.1^{\mathrm{b}}$ & $1.11^{\mathrm{cd}}$ & 2. $26^{\mathrm{c}}$ & $0.46^{\mathrm{abc}}$ \\
\hline 7 & & 500 & $-11.6^{\mathrm{bc}}$ & $-7.8^{\mathrm{ab}}$ & $1.71^{\mathrm{b}}$ & 3. $27^{\mathrm{b}}$ & $0.42^{\mathrm{abcd}}$ \\
\hline 8 & & 1,000 & $-12.5^{\mathrm{ab}}$ & $-8.6^{a}$ & $2.34^{\mathrm{a}}$ & $3.74^{\mathrm{a}}$ & $0.44^{\mathrm{abcd}}$ \\
\hline 9 & \multirow{4}{*}{ Solution } & 0 & $-8.8^{e}$ & $-3.3^{\mathrm{e}}$ & $0.27^{\mathrm{g}}$ & $0.30^{\mathrm{g}}$ & $0.21^{\mathrm{d}}$ \\
\hline 10 & & 250 & $-9.1^{\mathrm{e}}$ & $-3.1^{\mathrm{e}}$ & $0.53^{\mathrm{f}}$ & $0.93^{\text {ef }}$ & $0.27^{\mathrm{cd}}$ \\
\hline 11 & & 500 & $-9.0^{\mathrm{e}}$ & $-3.2^{\mathrm{e}}$ & $0.90^{\mathrm{de}}$ & $1.11^{\mathrm{ef}}$ & $0.41^{\mathrm{abcd}}$ \\
\hline 12 & & 1,000 & $-8.8^{e}$ & $-3.8^{e}$ & $0.83^{e}$ & $1.17^{\mathrm{e}}$ & $0.52^{\mathrm{ab}}$ \\
\hline \multirow{4}{*}{\multicolumn{2}{|c|}{ Mean $\mathrm{Cl}$ concns }} & 0 & $-9.5^{\mathrm{c}}$ & $-5.0^{\mathrm{D}}$ & $0.37^{\mathrm{D}}$ & $0.97^{\mathrm{D}}$ & $0.23^{\mathrm{C}}$ \\
\hline & & 250 & $-10.6^{\mathrm{B}}$ & $-5.8^{\mathrm{C}}$ & $0.95^{\mathrm{C}}$ & $2.09^{\mathrm{C}}$ & $0.33^{\mathrm{BC}}$ \\
\hline & & 500 & $-10.9^{\mathrm{B}}$ & $-6.3^{\mathrm{B}}$ & 1. $43^{\mathrm{B}}$ & $2.76^{\mathrm{B}}$ & $0.38^{\mathrm{B}}$ \\
\hline & & 1,000 & $-11.4^{\mathrm{A}}$ & $-6.9^{A}$ & $1.82^{\mathrm{A}}$ & $2.96^{\mathrm{A}}$ & $0.53^{\mathrm{A}}$ \\
\hline \multirow{3}{*}{\multicolumn{2}{|c|}{ Mean media }} & Soil & $-11.5^{\mathrm{x}}$ & $-7.3^{\mathrm{x}}$ & 1. $41^{\mathrm{x}}$ & $3.20^{\mathrm{x}}$ & $0.36^{x}$ \\
\hline & & Sand & $-11.4^{\mathrm{x}}$ & $-7.2^{\mathrm{x}}$ & 1. $38^{\mathrm{x}}$ & $2.51^{\mathrm{Y}}$ & $0.39^{x}$ \\
\hline & & Solution & $-8.9^{\mathrm{Y}}$ & $-3.4^{\mathrm{Y}}$ & $0.63^{\mathrm{Y}}$ & $0.88^{Z}$ & $0.35^{\mathrm{x}}$ \\
\hline
\end{tabular}

*: The same as Table 2. 
Table 5. Effect of sea water concentrations on certain elements in leaves of muskmelons grown in different media ( $\%$ of dry matter).

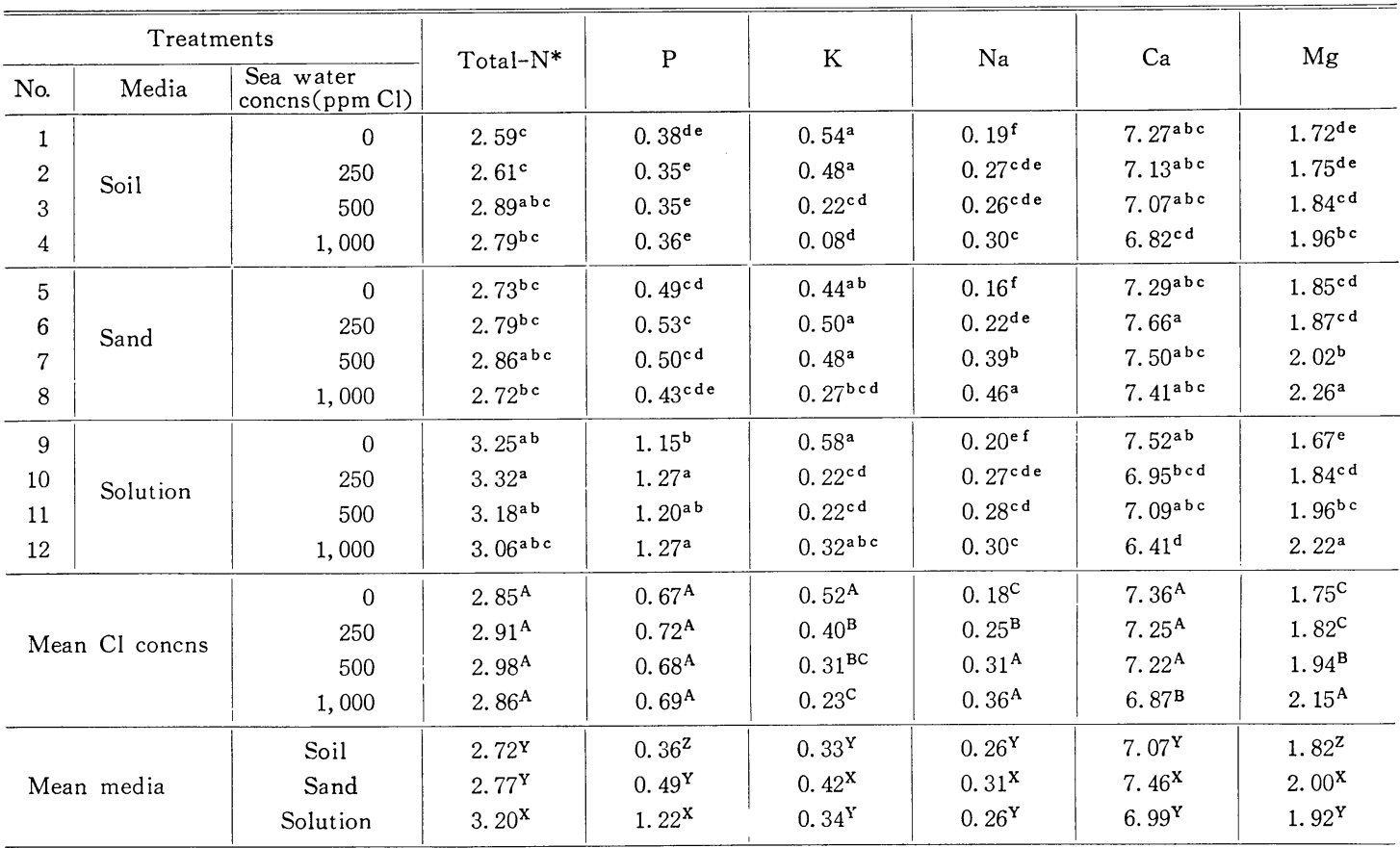

*: The same as Table 2.

Table 6. Chemical properties of soil and sand at the end of the experiment.

\begin{tabular}{|c|c|c|c|c|c|c|c|c|c|c|c|}
\hline \multicolumn{3}{|c|}{ Treatments } & \multicolumn{4}{|c|}{ Exchangeable cations $(\mathrm{me} / 100 \mathrm{~g})^{*}$} & \multirow{2}{*}{$\begin{array}{l}\mathrm{NO}_{3}-\mathrm{N} \\
(\mathrm{ppm})\end{array}$} & \multirow{2}{*}{$\begin{array}{c}\text { P(Truog) } \\
(\mathrm{ppm})\end{array}$} & \multirow{2}{*}{$\begin{array}{c}\mathrm{Cl} \\
(\mathrm{ppm})\end{array}$} & \multirow{2}{*}{$\begin{array}{l}\mathrm{EC}(1: 5) \\
(\mathrm{m} \mho / \mathrm{cm})\end{array}$} & \multirow{2}{*}{$\begin{array}{c}\mathrm{pH} \\
\left(\mathrm{H}_{2} \mathrm{O}\right)\end{array}$} \\
\hline No. & Media & $\begin{array}{l}\text { Sea water } \\
\text { concns }(\mathrm{ppm} \mathrm{Cl})\end{array}$ & $\mathrm{K}$ & $\mathrm{Na}$ & $\mathrm{Ca}$ & $\mathrm{Mg}$ & & & & & \\
\hline 1 & \multirow{4}{*}{ Soil } & 0 & $2.58^{\mathrm{a}}$ & 1. $27^{\mathrm{d}}$ & $10.27^{\mathrm{a}}$ & $3.93^{c}$ & $50^{\mathrm{b}}$ & $44^{\mathrm{a}}$ & $91^{\mathbf{e f}}$ & $1.01^{\mathrm{c}}$ & 4. $42^{\mathrm{a}}$ \\
\hline 2 & & 250 & 2. $69^{\mathrm{a}}$ & $2.89^{c}$ & $10.71^{\mathrm{a}}$ & 4. $23^{\mathrm{b}}$ & $62^{\mathrm{a}}$ & $43^{\mathrm{a}}$ & $777^{\mathrm{c}}$ & $1.76^{\mathrm{b}}$ & 4. $52^{\mathrm{a}}$ \\
\hline 3 & & 500 & $2.60^{a}$ & 4. $86^{\mathrm{b}}$ & $10.04^{a}$ & 4. $35^{b}$ & $60^{\mathrm{ab}}$ & $47^{\mathrm{a}}$ & $1,050^{b}$ & $1.84^{\mathrm{b}}$ & $4.72^{\mathrm{a}}$ \\
\hline 4 & & 1,000 & $2.55^{\mathrm{a}}$ & $6.43^{\mathrm{a}}$ & $10.09^{a}$ & $4.63^{\mathrm{a}}$ & $71^{\mathrm{a}}$ & $38^{\mathrm{ab}}$ & $1,800^{\mathrm{a}}$ & $2.29^{\mathrm{a}}$ & 4. $43^{\mathrm{a}}$ \\
\hline 5 & \multirow{4}{*}{ Sand } & 0 & $0.48^{\mathrm{b}}$ & $0.29^{g}$ & $1.56^{\mathrm{b}}$ & $0.37^{\mathrm{d}}$ & $12^{\mathrm{c}}$ & $26^{\mathrm{c}}$ & $7^{\mathrm{f}}$ & $0.32^{\mathrm{d}}$ & 4. $93^{\mathrm{a}}$ \\
\hline 6 & & 250 & $0.51^{b}$ & $0.53^{\mathrm{f} g}$ & $1.34^{\mathrm{b}}$ & $0.35^{d}$ & $16^{\mathrm{c}}$ & $25^{c}$ & $73^{f}$ & $0.33^{\mathrm{d}}$ & 4. $42^{\mathrm{a}}$ \\
\hline 7 & & 500 & $0.49^{b}$ & $0.75^{\mathrm{ef}}$ & $1.18^{\mathrm{b}}$ & $0.38^{\mathrm{d}}$ & $15^{c}$ & $26^{\mathrm{c}}$ & $177^{\mathrm{de}}$ & $0.36^{\mathrm{d}}$ & 4. $61^{\mathrm{a}}$ \\
\hline 8 & & 1,000 & $0.47^{\mathrm{b}}$ & $0.95^{\mathrm{e}}$ & $0.89^{\mathrm{b}}$ & $0.42^{\mathrm{d}}$ & $15^{\mathrm{c}}$ & $30^{b}$ & $262^{\mathrm{d}}$ & $0.37^{\mathrm{d}}$ & 5. $14^{\mathrm{a}}$ \\
\hline \multirow{4}{*}{\multicolumn{2}{|c|}{$\begin{array}{l}\text { Mean } \mathrm{Cl} \\
\text { conens }\end{array}$}} & 0 & $1.53^{\mathrm{A}}$ & $0.78^{\mathrm{D}}$ & $5.91^{\mathrm{A}}$ & $2.15^{\mathrm{B}}$ & $31^{B}$ & $34^{\mathrm{A}}$ & $49^{D}$ & $0.67^{\mathrm{c}}$ & 4. $68^{\mathrm{A}}$ \\
\hline & & 250 & 1. $60^{\mathrm{A}}$ & $1.71^{\mathrm{C}}$ & 6. $03^{\mathrm{A}}$ & 2. $29^{\mathrm{AB}}$ & $39^{\mathrm{AB}}$ & $34^{\mathrm{A}}$ & $425^{\mathrm{C}}$ & $1.04^{\mathrm{B}}$ & 4. $47^{\mathrm{A}}$ \\
\hline & & 500 & $1.55^{\mathrm{A}}$ & $2.81^{\mathrm{B}}$ & $5.58^{\mathrm{A}}$ & 2. $37^{\mathrm{AB}}$ & $38^{\mathrm{AB}}$ & $37^{\mathrm{A}}$ & $614^{\mathrm{B}}$ & 1. $10^{\mathrm{B}}$ & 4. $67^{\mathrm{A}}$ \\
\hline & & 1,000 & 1. $51^{\mathrm{A}}$ & 3. $69^{\mathrm{A}}$ & 5. $49^{\mathrm{A}}$ & $2.52^{\mathrm{A}}$ & $43^{\mathrm{A}}$ & $35^{\mathrm{A}}$ & $1,031^{\mathrm{A}}$ & 1. $33^{\mathrm{A}}$ & 4. $79^{\mathrm{A}}$ \\
\hline \multirow{2}{*}{\multicolumn{2}{|c|}{ Mean media }} & Soil & $2.60^{\mathrm{x}}$ & $3.87^{x}$ & $10.28^{\mathrm{X}}$ & $4.28^{\mathrm{x}}$ & $61^{x}$ & $43^{x}$ & $930^{x}$ & $1.72^{x}$ & $4.52^{x}$ \\
\hline & & Sand & $0.49^{\mathrm{Y}}$ & $0.63^{\mathrm{Y}}$ & 1. $23^{\mathrm{Y}}$ & $0.38^{\mathrm{Y}}$ & $14^{\mathrm{Y}}$ & $27^{\mathrm{Y}}$ & $130^{\mathrm{Y}}$ & $0.35^{\mathrm{Y}}$ & $4.78^{\mathrm{x}}$ \\
\hline
\end{tabular}

*: The same as Table 2 .

soil culture, as shown in Table 2 and 3. However, the relative plant growth as expressed by percentage of $0 \mathrm{ppm} \mathrm{Cl}$ was most suppressed in sand culture. The decrement in soil culture was to some extent less than in sand culture. For example, the relative plant dry weight at $1,000 \mathrm{ppm} \mathrm{Cl}$ to $0 \mathrm{ppm} \mathrm{Cl}$ was $56.0,83.5$ and $91.0 \%$ in sand, soil and nutrient solution cultures, respectively. The relative fresh weight of plant parts was sim- 
ilar to the results of the plant dry weight.

The plant growth reduction by the application of diluted sea water could be associated with not only higher concentrations of potentially toxic ions but also lower osmotic potential of plants and media (6). It is considered $(5,16)$ that the reduction in plant growth is primarily associated with osmotic potential of the medium, but in some plants nutritional imbalance or toxicity of specific ions are also important factors (7).

It is possible that one of the reasons for the difference of growth reduction in different media is the specific ion effect. There was an increase in $\mathrm{Na}$ content in leaves and $\mathrm{Cl}$ content in leaves, roots and fruit in each medium when sea water concentrations increased. On the other hand, the descending order of relative amounts of $\mathrm{Cl}$ and $\mathrm{Na}$ in leaves was sand, soil and nutrient solution cultures. The relative amount of $1,000 \mathrm{ppm} \mathrm{Cl}$ compared to $0 \mathrm{ppm} \mathrm{Cl}$ in sand, soil and nutrient solution cultures for $\mathrm{Cl}$ was $6.7,4.8$ and 3.1 times and for $\mathrm{Na}$ was 2.9, 1.6 and 1.5 times, respectively. The order is in the same relationship as that of relative plant growth. Therefore, the increased $\mathrm{Cl}$ and $\mathrm{Na}$ in leaves seemed to cause some adverse effects on plant growth as observed by many investigators $(2,8,12,13,14,15,17)$.

Another possible reason for the difference of plant growth reduction is low osmotic potential of leaves and roots. The leaf and root osmotic potential in nutrient solution culture was markedly higher than in sand and soil cultures, and was not significantly different from 0 to $1,000 \mathrm{ppm} \mathrm{Cl}$. These results are comparable in that the relative plant growth in nutrient solution culture was greater than in the other cultures, and the growth was slightly suppressed even at $1,000 \mathrm{ppm} \mathrm{Cl}$. It may be due to differences of root system, root weight and osmotic potential of the medium between nutrient solution culture and the others. The plant growth in soil and sand cultures decreased with decreasing osmotic potentials of applied diluted sea water in each medium. However, there was no significant difference in the osmotic potential of leaves and roots between soil and sand cultures. As to the result between in sand and soil cultures, restricting water absorption induced by high salinity (18) could not be a cause of plant growth reduction.

The chemical properties of the sand and soil at the end of the experiment (Table 6) did not account for the difference in plant growth suppression between sand and soil cultures. Although $\mathrm{Na}$ and $\mathrm{Cl}$ content, and EC values increased with increasing diluted sea water concentrations in each medium, they were higher in soil culture than in sand culture. This result is contradictory in that the plant growth was more suppressed in sand culture than in soil culture. Because each medium has different physical properties, these factors should be taken into consideration when the chemical properties between sand and soil are compared. It is supposed that the osmotic potential of the medium solution might be lower in sand culture than in soil culture (2). This may be suggested by the fact that $\mathrm{Cl}$ and $\mathrm{Na}$ content in plant parts were higher in sand culture than in soil cutlure.

\section{Acknowledgement}

Recognition is given Dr. W. J. Clore for his critical reading of this manuscript.

\section{Literature Cited}

1. Ayers, A. D., C. H. WAdLeigh, and L. BERNSTEIN. 1951. Salt tolerance of six varieties of lettuce. Proc. Amer. Soc. Hort. Sci. $57: 237-242$.

2. AYOUB, A. T. 1975. Sodium and cation accumulation by senna (Cassia acutifolia). J. Expt. Bot. $26: 891-896$.

3. BATChELdER, A. R., J. LUNiN, and M. H. GALLATIN。1963. Saline irrigation of several vegetable crops at various growth stages. II. Effect on cation composition of crops and soils. Agron. J. 55 : 111-114.

4. Bernstein, L., and A. D. AyerS. 1951. Salt tolerance of six varieties of green beans. Proc. Amer. Soc. Hort. Sci. 57 : 243-248.

5. Bernstein, L., and G. A. Pearson. 1954. Influence of integrated moisture stress achieved by varying the osmotic pressure of culture solutions on growth of tomato and pepper plants. Soil Sci. $77: 355-368$.

6. BERNSTEIN, L., and H. E. HAYWARD. 1958. 
Physiology of salt tolerance. Ann. Rev. Plant Physiol. $9: 25-46$.

7. DIRR, M. A. 1974. Tolerance of honeylocust seedlings to soil-applied salts. HortScience $9: 53-54$.

8. EhLiG, C. H., and L. Bernstein. 1958. Salt tolerance of strawberries. Proc. Amer. Soc. Hort. Sci. 72 : 198-206.

9. Gallatin, M. H., J. Lunin, and A.R. BATCHELDER. 1963. Brackish water irrigation of several vegetable crops in humid regions. Agron. J. 55 : 383-386.

10. Lunin, J., M. H. Gallatin, and A.R. BATCHELDER. 1963. Saline irrigation of several vegetable crops at various growth stage. I. Effect on yields. Agron. J. $55: 107-$ 111.

11. MASUi, M., A. NUKAYA, and A. IShidA. 1975. Salt content of well water of greenhouse growers in Shizuoka Prefecture. Bull. Fac. Agr., Shizuoka Univ. Japan. $25: 15-22$. (Japanese with English summary).

12. NUKAYA, A., M. MASUI, A. ISHIDA, and T. OGURA. 1977. Salt tolerance of green soybeans. J. Japan. Soc. Hort. Sci. $46: 18-25$.

13. NUKAYA, A., M. MASUI, and A. ISHIDA. 1979. Salt tolerance of tomatoes. J. Japan. Soc.
Hort. Sci. $48: 73-81$.

14. NUKAYA, A., M. MASUI, and A. ISHIDA. 1980. Salt tolerance of muskmelons grown in different salinity soils. J. Japan. Soc. Hort. Sci. $48: 468-474$.

15. NUKAYA, A., M. MASUI, and A. ISHIDA. 1980. Salt tolerance of muskmelons in sand and nutrient solution cultures. J. Japan. Soc. Hort. Sci. 49 : 93-101.

16. OSAWA, T. 1963. Studies on the salt tolerance of vegetable crops with special reference to osmotic effects and specific ion effects. J. Japan. Soc. Hort. Sci. $32: 211-223$. (Japanese with English summary).

17. Shannon, M. C., and L. E. FrancoIS. 1978. Salt tolerance of three muskmelon cultivars. J. Amer. Soc. Hort. Sci. $103: 127-130$.

18. SHImadA, N. 1969. Studies on the salt injury of crops (Part 1). On the root activity of cucumber seedlings in single salt solutions. J. Sci. Soil \& Manure, Japan. $40: 26-31$. (Japanese).

19. SonNeveld, C., and J. van Beusekom. 1974. The effect of saline irrigation water on some vegetables under glass. Acta Horticulturae. $35: 75-85$.

\section{異なる培地におけるメロンの耐塩性}

糠谷 明 - 増井正夫 - 石田 明

(静岡大学農学部)

\footnotetext{
摘

異なる培地におけるメロンの耐塩性を調べるため, 同 一条件下でメロンを栽培した。草丈は，砂耕と土耕にお いて海水濃度が增すにつれ減少した。 $0 \mathrm{ppmCl}$ を100 と した場合の全植物体乾物重と果実新鮮重は, 養液耕, 土 耕の順に大きく, 砂耕では最も小さかった. $0 \mathrm{ppmCl} に$ 対する $1,000 \mathrm{ppmCl}$ の果実新鮮重の割合は, 砂耕で 66.2 \%，土耕で 70.5\%，養液耕で $91.1 \%$ であった．それぞ 要

れの培地において海水濃度が増すにつれ，葉と根の浸透 ポテンシャルは減少し, 植物体各部の $\mathrm{Cl}$ 含量, 葉中の $\mathrm{Na}$ と $\mathrm{Mg}$ 含量は増加した. 葉中の $\mathrm{Cl}$ と $\mathrm{Na}$ 含量は 砂耕で最も高く，養液耕で最も低かった，土壤と砂の $\mathrm{C} 1$ 及び置換性 $\mathrm{Na}$ 含量, 土壤の $\mathrm{EC}$ は, 海水濃度が増 すにつれて增加した．培地のカチオンとアニオン含量, EC は砂耕より土耕で高かった。
} 